\title{
Exploitation of Renewable Energy Sources and Its Legal Regulation
}

\author{
Boyu Zhu \\ School of Law, Shandong University of Technology \\ Zibo 255049, Shandong, China \\ E-mail: zhuboyu123@126.com
}

Focus Research Project of Social Science in Shandong Province "Theory and Practice of Legal Construction about Circular Economy" (No: 08JBC015); Research Project of Soft Science in Shandong Province "Study on Legal issues about Circular Economy" (No: 2008RKB142); International Cooperation and Training Project of Excellent University Key Teachers in Shandong Province.

\begin{abstract}
There is great potential for exploitation of renewable energy sources in China, but the strength of policy support and stimulation measures is far from enough. Many practices in foreign countries to lead and standardize development of renewable energy sources can be used as sources of reference in China. The People's Republic of China Renewable Energy Law and relevant supporting regulations have stimulated and promoted exploitation of renewable energy sources in China.
\end{abstract}

Keywords: Renewable energy sources, Legal regulation

Renewable energy sources refer to energy sources that can be regenerated and sustainably utilized in the nature, including non-fossil energy, such as, wind energy, solar energy, water power, biomass energy, geothermal energy and ocean energy, etc. Energy is the necessary and fundamental material guarantee for production and living of human beings. For the time being, finiteness of fossil energy in the world and environmental issues caused in its exploitation seriously restrict development of circular economy. Exploitation of renewable energy sources has received high concentration from the whole world. Quite a lot of countries regard exploitation of renewable energy sources as a significant component of developing circular economic strategy, and lead and standardize development of renewable energy sources by means of the law, which can be used as reference in China.

\section{Status quo of exploitation of renewable energy sources in China}

So far, China has become the second largest country in production of energy and consumption of energy. Renewable energy sources in China are extremely abundant. It is calculated by the National Development and Reform Committee (NDRC), in the following twenty to thirty years, the following renewable energy sources will produce 800 million tons of standard coal each year: small hydro power, wind energy, solar energy and biomass energy, etc, which is able to fulfill conditions of utilization, and have great potential for exploitation. Considering development of renewable energy sources in China, China is leading the world in total utilization capacity of small hydro power, biogas and solar water heater.

\subsection{Wind energy}

With a vast territory and long coastline, China is abundant in wind energy sources. It is preliminarily estimated, available wind energy sources on the land are approximately 250 million kilowatt, and maritime wind energy sources are approximately 750 kilowatt, altogether 1 billion kilowatt or so. Wind power construction in China dated from 1980s, and with development for more than 20 years, synchronization wind farms with a large scale have been constructed in the country.

\subsection{Solar energy}

Most regions of China are located in the south of the north latitude 45', and are abundant in solar energy sources. Solar energy utilization in China is mainly concentrated in solar energy power generating and solar water heater. By the end of 2005, the total installed capacity of solar photovoltaic had reached approximately 70 thousand kilowatt around the 
whole country, which was mainly utilized to resolve residential power utilization in remote areas and to satisfy demands of particular commercial power utilization (decentralized power, such as communications, navigation and traffic, etc). The industry of solar water heater in China is relatively mature, and its yield capacity and amount of usage rank the first in the world.

\subsection{Biomass energy}

Biomass energy sources in China are also extremely abundant. Cultivation area of crops in China occupies 1.5 billion Mou, and annual production of biomass is about 700 tons. In addition to being used as papermaking raw material and animal husbandry and feed, all remaining part is used as fuels. The existing forestry area in China is about 175 million hectare, and each year, approximately 0.8 to 1 billion tons of biomass sources can be acquired by means of normal bush stump and rejuvenation, forest thinning, trimming of fruit trees and green fences, and collecting forest harvested, rough-hew and processed remainders. At the same time, there are more than 46 million hectare of forestation-suitable land that can be used to grow energy plants by considering ecological construction. Municipal refuse is also a sort of important biomass sources. Current quantity of refuse in urban areas reaches about 130 million tons, and with development of urbanization, the quantity of refuse will be on a continual increase. At present, biomass energy is still an important living energy source in many rural areas in China, but mostly are in the form of traditional utilization with low efficiency. The most successful utilization of biomass energy through modernized technology is biogas technology, especially rural household biogas technology. China also has had an installed capacity of over 2 million kilowatt in generators. Forms of biomass generating mainly include agricultural wastes of bagasse, rice hulls, forestry wastes, biogas and garbage power, etc. From the perspective of sources, garbage may be the unique ever-increasing renewable energy source on the earth. Therefore, recycling utilization of garbage seems extremely significant. Generating through waste incineration is an important approach to recycling utilization of garbage. Currently, annual production capacity of urban refuse in China is about 120 million tons, and it will continue to increase with development of urbanization. Annual production capacity of rural straws exceeds 600 million tons, and there is huge potential to make full use of biogas and exploit new types of fuel or generating. In addition, the project of using aged grain to produce alcohol fuels is being pushed forward, with an anticipated annual production capacity of 1 million tons and the technique of utilizing energy sources and crops to produce alcohol fuels and biodiesel is also being tested and demonstrated.

\subsection{Hydroelectric power}

China has abundant hydraulic power sources, which are the most important energy sources. Exploitable capacity of economy in China is 400 kilowatt and its annual power generation is approximately 1.74 trillion kilowatt-hour. By the end of the year 2005, the total installed capacity of hydropower station had reached 117 million kilowatt all over the country, accounting for one fourth of the total installed capacity of generators, and the annual power generation capacity had been 390 billion kilowatt-hour, accounting for $16 \%$ of the total power generation capacity.

Although exploitation of renewable energy sources has attained great achievements in China, the strength of policy support and stimulation measures is far from enough. At the current technical level and under the current policy environment, except that hydraulic power and solar water heater are qualified to participate in market competition, a large majority of renewable energy sources have too high exploitation cost, together with characteristics of disperse sources, small scales and discontinuity of production, so they are short of competitive strength in the current market condition and are in urgent need of relevant regulations and policies.

\section{Policy and legal regulations on exploitation of renewable energy sources in foreign countries}

In the past few years, renewable energy sources have got rapid development all over the world. Renewable energy sources have become important alternative energy sources to realize energy diversification and circular economy. Development of renewable energy sources has been widely concentrated by many countries and has become a hot issue in the field of international energy.

In 1997, European Union issued a white paper for development of renewable energy sources, and formulated the magnificent target, that is, renewable energy would account for $12 \%$ of total EU energy consumption by 2010 and would account for 50\% of energy source composition in all members in EU by 2050. In 2001, EU Council of Ministers proposed the common instruction about generating of renewable energy sources, and required EU members to realize the control target of renewable energy sources accounting for $12 \%$ of all energy consumption and $22.1 \%$ in the total power consumption by 2010. US Department of Energy put forward the development plan of gradually increasing green power, and formulated technical development roadmap of wind power generation, solar power generation and biomass generation in the hope of increasing proportion of green energy resources by all these means. Since 1993, Japan has begun to carry out "New Sunshine Program" to accelerate exploitation of photovoltaic cell, fuel cell, hydrogen energy and geothermal energy, etc. In 1997, Japan announced a roof plan of 70 thousand solar photovoltaic with a view to installing solar cell of 7.6 million KV. As early as in 1970s, Brazilian government began to implement development plan of biofluid, and developed alcohol fuels with raw materials of cane and cassava, etc. 
Renewable Energy Law belongs to part of legal system of circular economy. It can even be said, the core issue of legal system of circular economy is legal regulations on regeneration of energy. Some foreign countries have realized strategic significance of renewable energy to the future very early, and have conducted relevant legislative activities. In 1990, Germany formulated <<Stromeinspeisungsgesetz $>>$, which stipulated that medium-and-large-sized power consumers should pay electricity generated by means of wind power, solar energy, hydraulic and biomass energy at a price of $90 \%$ of residential power price. For wind power generation, German government pays subsidy in accordance with quantity of power output or facility cost. As for enterprises with investment in renewable energy sources, the country provides them with a preferential loan equivalent to $75 \%$ of facility investment cost at a favorable interest rate $1-2 \%$ lower than the market interest rate. In 1997, Japan formulated $<<$ New Energy Law $>>$, and such countries as Denmark, Holland and Britain, etc, also rapidly promoted the industry of renewable energy sources by adopting a series of policies and legal systems.

It should be particularly mentioned that, $<<$ Emeuerbare Energien Gesetz $>>$ by Germany is one of the most advanced legislations about clean energy in the world, and most of its principles and specific items are of great innovation. They have given full play in practice and have promoted development of renewable energy sources in Germany to great extent. On February 25, 2000, German Parliament passed $<<$ Emeuerbare Energien Gesetz $>>$ (abbreviated as EEG). This law is established on the basis of successful experiences of $<<$ Law of Mains Supply through Renewable Energy Generation $>>$, and is regarded as the most advanced legislation about clean renewable energy sources in the world. The $<<$ Law of Mains Supply through Renewable Energy Generation >>, which took effect from January 1, 1991, focused on development of wind power. However, this law hasn't promoted other energy sources to enter the market on a large scale, especially photovoltaic cell and biomass energy. Therefore, $<<$ Emeuerbare Energien Gesetz $\gg$ made new provisions, with the purpose of promoting generating of all sorts of renewable energy sources. Generally speaking, $<<$ Emeuerbare Energien Gesetz > facilitated development of renewable energy generation by setting the obligation of purchasing electricity on power grid operators. To stipulate fixed on-grid price of renewable energy power is a prominent feature of $\langle<$ Emeuerbare Energien Gesetz $>>$. Fixed electricity price system (also called mandatory feed in law) (Note 1), refers to a system in which a country determines on-grid price of its renewable energy power according to actual generating cost of generation technology in various renewable energy sources or according to average price of electricity, and requires power on-grid enterprises to purchase renewable energy power produced by renewable energy developers. Germany is a typical country which implements fixed electricity price system of renewable energy sources, and this system has gained tremendous achievements in exploitation of renewable energy sources. In August 2004, the newly revised $<<$ Emeuerbare Energien Gesetz $>>$ came into force, which proposed the new target: generated renewable energy accounting for $20 \%$ of gross generation will be adequately and legally guaranteed by 2020 and development of renewable energy sources will have solider foundation and broader space.

\section{Legal regulations on exploitation of renewable energy sources in China}

Exploitation of renewable energy sources earlier in China was aimed at resolving rural energy shortage. As early as 1970s, Chinese government issued some policies to support construction of renewable energy sources in rural areas, such as development of hydropower, popularization and application of biogas in rural households, and popularization of firewood-saving, etc. Unveiling of these policies and measures enabled China to take a leading position among developing countries in exploitation of renewable energy sources and also to maintain an advanced level in the world.

In terms of laws, regulations and administrative regulations, China has made stipulations to encourage exploitation of clean energy, including renewable energy sources, in $<<$ Electricity Act $>>,<<$ Energy Conservation Law $>>$ and $<<$ Air Pollution Control Law $>>$ etc, which were passed earlier. In some administrative regulations issued by departments concerned of the State Council, such as "national policies of energy technology", "industries, products and technical catalogs developed with focus currently", "notification on some issues to further support development of renewable energy sources", and "administrative provisions on wind power generation through synchronization", etc, the country also has made decisions to encourage exploitation of renewable energy sources and to carry out mandatory electricity on-grid and economic incentive, etc, to stimulate development of renewable energy sources. On February 28, 2005, the $14^{\text {th }}$ Meeting of the $10^{\text {th }}$ NPC Standing Committee passed $<<$ Renewable Energy Law of P.R. China $>>$, which raised exploitation of renewable energy sources to a strategic height of "increasing energy supply, improving energy structure, ensuring energy security, protecting the environment and realizing sustainable development of an economic society.

$<<$ Renewable Energy Law of P.R. China $>>$ is the first law in China in the field of renewable energy sources, and it has established some important legal systems as follows: the target system of gross amount of renewable energy sources, approval of renewable energy generation through synchronization and full acquisition system; on-grid price and cost allocation system of renewable energy sources; financial incentives. Generally speaking, <<Renewable Energy Law $>>$ is a framework method of policies, and its effective implementation depends on the State Council and departments concerned to unveil in due time assorted administrative rules, regulations, technical standards and corresponding development plans. After $<<$ Renewable Energy Law $>>$ was passed, the National People's Congress and departments 
concerned of the State Council issued some specific policies and measures, mainly including generation and on-grid of renewable energy sources, fixed electricity price, cost allocation, standard rules, special fund, taxation and credit policies, etc, such as, $<<$ Experimental Method for Management on Price of Electricity Generation from Renewable Energy and Cost Allocation $>>,<<$ Management Regulations for Electricity Generation from Renewable Energy $>>$ and $<<$ Interim Measures on Special Fund Management for Development of Renewable Energy $>>$, etc.

It is stipulated in $<<$ Experimental Method for Management on Price of Electricity Generation from Renewable Energy and Cost Allocation $>>$, price of electricity generation from renewable energy sources is set and directed by the government, that is, to determine tender price via bid inviting. $<<$ Experimental Method $>>$ makes the following stipulations on price of generation from renewable energy sources: price of hydroelectric power is temporarily based on the existing provision; on-grid price of wind power generation project is directed by the government, and price of electricity is established based on the price formed in bidding by Price Competent Department of the State Council; on-grid price of solar power generation, ocean power generation and geothermal energy generation projects is set by the government, and the standard of price is determined by Price Competent Department of the State Council based on the principle of rational cost plus rational profit; on-grid price of biomass generation project is set by the government and the standard of price is composed of on-grid price of desulfurization coal-fired unit benchmarking pool in all provinces (autonomous regions and municipalities) in 2005 plus subsidized price of 0.25 Yuan per kilowatt-hour. $<<$ Management Regulations for Electricity Generation from Renewable Energy $>>$ defines management at different levels by Central Government and local governments for power generation projects of renewable energy sources, and stipulates the plan of generation from renewable energy sources should be brought into electricity program at the same level. In addition, $<$ Management Regulations $>>$ requires, generating enterprises should take the initiative to invest and establish programs of electricity generation from renewable energy sources, and undertake obligation of generation quota in renewable energy sources specified by the country; large-scale generating enterprises should give priority to investment in programs of power generation from renewable energy sources. $<$ Interim Measures on Special Fund Management for Development of Renewable Energy $>>$ stipulates, special funds for development should be arranged by means of central budget, and should be mainly used to support exploitation of renewable energy sources, such as, substitutes of petroleum with great potential and good prospects, heat supply, heating and refrigeration of buildings, and electricity generation, etc.

Price of renewable energy sources has been an outstanding issue in development of renewable energy sources. Auxiliary regulations of $<<$ Renewable Energy Law $>>$ define price of renewable energy sources. Investment in renewable energy sources may bring considerable profits, so more and more enterprises will be involved in this field.

\section{References}

Li, Junfeng \& Shi, Jingli. (2006). International and Chinese incentive policies on promoting renewable energy development and relevant proposals. Renewable Energy, No. 1, 1-2.

Li, Yanfang. (2005). System Construction and Selection of "Renewable Energy Law" in China. Journal of Renmin University of China, No. 1, 135.

Shi, Lishan. (2004). Issues of Energy in China and Development Program of Renewable Energy. Energy Policy Research, No. 3, 17-21.

\section{Notes}

Note 1. Fixed electricity price system and portfolio standard are two major systems in development of renewable energy sources. Quota of renewable energy sources refers the system in which a country or region executes mandatory provision on portion of renewable energy in the total power supply by legal means, and in which electricity price is determined by the market so as to promote development of renewable energy sources. Britain and America (represented with Texas) are typical countries which carry out the Portfolio Standard, whereas Germany is a typical country which carries out fixed electricity price system. 